\begin{abstract}
Recent research in labour economics (e.g. the work of Card and Krueger, 1995, on the impact of minimum wages) has led to renewed interest in the appropriate model to use when thinking about the labour market. But, the standard textbook models of both perfect competition and monopsony are both implausible, though for different reasons. The competitive model because it assumes the wage elasticity of the supply of labour to the individual firm is infinite and the monopsony model because it assumes that an employer cannot do anything to raise employment other than raise the wage. This paper presents a more general but very simple model in which the employer can also raise employment by increasing expenditure on recruitment.

Using this, it is shown how that division between perfect competition and monopsony is not the issue of whether the wage elasticity in labour supply is infinite or finite (as it is usually presented) but whether there are diseconomies of scale in recruitment. Using a unique British data set containing information on both labour turnover costs and the number of recruits, we present estimates that do suggest that there is an increasing marginal cost of recruitment.
\end{abstract}

JEL Classification: J63

Keywords: Labour Turnover

This paper was produced as part of the Centre's

Labour Markets Programme 
A Generalised Model of Monopsony

Alan Manning

July 2001 
Published by

Centre for Economic Performance

London School of Economics and Political Science

Houghton Street

London WC2A $2 \mathrm{AE}$

(C) Alan Manning, submitted May 2001

ISBN $075301470 \mathrm{X}$

Individual copy price: $£ 5$ 


\section{A Generalised Model of Monopsony}

\section{Alan Manning}

Introduction $\quad 1$

1. The Labour Cost Function 2

2. The Impact of a Minimum Wage 5

3. The Data 7

4. Estimating the Labour Cost Function 9

5. Conclusions 10

Tables 12

$\begin{array}{ll}\text { Figures } & 16\end{array}$

$\begin{array}{ll}\text { Appendix } & 18\end{array}$

$\begin{array}{ll}\text { References } & 20\end{array}$ 


\section{Acknowledgements}

The data used in this paper is drawn from a survey of their members conducted by the Institute for Personnel Development: I would like to thank Thibaut Desjonqueres and Tanvi Desai for help with this data and seminar participants at CEP for their comments.

Alan Manning is the Programme Director of the Labour Markets Programme at the Centre for Economic Performance, London School of Economics and Professor in the Department of Economics at LSE. 


\section{Introduction}

Recent research in labour economics (e.g. the work of Card and Krueger, 1995, on the impact of minimum wages) has led to renewed interest in the appropriate model to use when thinking about the labour market. The textbook model of perfect competition is extreme in that it assumes that a wage cut of a cent causes all workers to instantaneously quit to get jobs elsewhere' ${ }^{1}$. But, many labour economists feel uncomfortable with using the main alternative that allows a finite response of labour supply to an individual firm to cuts in the wage, a monopsony model (or perhaps, more accurately, a model of oligopsonistic competition). One of the reasons for this unease is that, in the standard monopsony model, employers have only one instrument for determining their supply of labour: the wage. In reality, employers can spend resources on recruitment to influence the flow of recruits to the firm.

So both the standard perfectly competitive and monopsony models are rather implausible as normally stated, the former because it is not credible that the wage elasticity of labour supply to an individual firm is infinite and the latter because it is not credible to believe that the only thing an employer can do to raise employment is to raise the wage.

In this paper we show how an embarrassingly simple model in which the supply of labour to the firm can be influenced both by the wage and expenditure on recruitment activity neatly nests both the perfectly competitive model and the standard monopsony model. For this reason, we refer to it as a generalised monopsony model. Using this model we show how the debate between perfect competition and monopsony as tools to think about the labour market needs to be shifted away from the issue of the whether the wage elasticity of labour supply to the firm (given recruitment activity) is or is not infinite ${ }^{2}$. Instead, the debate should be about whether, for a given wage, there are diseconomies of scale in recruitment. Perfect competition is best thought of as a situation not in which the wage elasticity of the labour supply curve facing a firm is infinite for a given level of recruitment activity (which is not really credible) but in which the marginal cost of recruiting a worker is independent of the level of employment. On the other hand, 'monopsony' is shown to correspond to the case where the marginal cost of

1 There is an issue here about the size of the wage elasticity over different time horizons. But, taken literally, the perfectly competitive model assumes it is infinite over the smallest time horizon.

2 There is a literature, albeit surprisingly small (one might cite Reynolds, 1946; Nelson, 1973; Sullivan, 1989; Boal, 1995; Staiger, Spetz and Phibbs, 1999 as an almost complete list), which attempts to test the appropriate model by 
maintaining given stock of workers is increasing in employment. This may sound very similar to the usual condition for monopsony but the marginal cost of employment being increasing in the wage for a given level of recruitment activity is not sufficient for there to be monopsony power.

The next section outlines the basic model. It introduces the concept of the labour cost function and derives the condition under which the labour market will be 'competitive' or 'monopsonistic'. We then use data drawn from the UK Institute of Personnel Director's annual Labour Turnover Survey to try to estimate the labour cost function. We reject the hypothesis that the labour market is competitive as we do find evidence of diseconomies in recruitment.

\section{The Labour Cost Function}

Define the labour cost function, which we will denote by $\mathrm{C}(\mathrm{w}, \mathrm{N})$, as the cost per worker, excluding direct wage costs, of keeping employment at $\mathrm{N}$ when the firm pays a wage $\mathrm{w}$. Some examples might make the idea clearer. For example if recruiting and training a worker costs $\mathrm{H}(\mathrm{w})$ and the separation rate is $\mathrm{s}(\mathrm{w})$, a flow of $\mathrm{sN}$ recruits is needed to maintain employment at $\mathrm{N}$ so that $\mathrm{C}(\mathrm{w}, \mathrm{N})=\mathrm{H}(\mathrm{w}) \mathrm{s}(\mathrm{w})$. In this case, the labour cost function is independent of N. But, if it becomes increasingly hard to recruit and train workers so that the costs of training and recruitment are $\mathrm{H}(\mathrm{R}, \mathrm{w})$ where $\mathrm{R}$ is the flow of recruits then the labour cost function will be of the form $\mathrm{C}(\mathrm{w}, \mathrm{N})=\mathrm{H}(\mathrm{s}(\mathrm{w}) \mathrm{N}, \mathrm{w}) \mathrm{s}(\mathrm{w})$ in which case it will depend on employment. Below, we show that the dependence or not of $\mathrm{C}(\mathrm{w}, \mathrm{N})$ on $\mathrm{N}$ is of critical importance. The concept of the labour cost function used here is a static one: in the Appendix we show how a simple dynamic model reduces, in steady-state, to the static model when the interest rate is low relative to the separation rate $^{3}$.

Implicit or explicit labour cost functions can be found in many other papers. One of the first papers to point out the potential importance of turnover costs was Oi (1962) who analysed the implications for the responsiveness of the demand for labour to shocks in product demand. But there are many other parts of labour economics where turnover costs play an important role: the search models of Diamond (1982) and Pissarides (1990) (see Mortensen and Pissarides, 1999, for a recent

estimating the wage elasticity in the supply of labour to the firm. One should not confuse the paucity of this literature with the voluminous literature on the supply of labour to the market as a whole. 
review), the efficiency wage model of Salop (1979) and the dynamic monopsony model of Mortensen (1998) which is based on Burdett and Mortensen (1998).

One can think of the textbook models of both perfect competition and the static model of monopsony as being particular forms (albeit, non-differentiable) of the labour cost function. The perfectly competitive labour market model can be represented in the following way. If there are no recruitment/training costs ${ }^{4}$ then, if $\mathrm{w}^{\mathrm{c}}$ is the competitive wage, the labour cost function for the competitive model can be represented by:

$$
\begin{aligned}
& C(w, N)=0 \quad \text { if } \quad w \geq w^{c} \\
& C(w, N)=\infty \quad \text { if } \quad w<w^{c}
\end{aligned}
$$

This is represented in Figure 1a. (1) says that any amount of labour can be recruited at zero cost as long as the wage paid is at or above the competitive level, but that no labour is available at any cost if a wage below the competitive wage is offered.

The traditional static monopsony model implicitly assumes that a firm that pays a wage $\mathrm{w}$ incurs no recruitment costs if it wants employment less than the labour supply forthcoming at that wage, $\mathrm{N}^{\mathrm{s}}(\mathrm{w})$, but that there is no way at all for the firm to attract more workers. So, the form of the labour cost function in this model is:

$$
\begin{aligned}
& C(w, N)=0 \quad \text { if } \quad N \leq N^{s}(w) \\
& C(w, N)=\infty \quad \text { if } \quad N>N^{s}(w)
\end{aligned}
$$

This is represented in Figure $1 \mathrm{~b}$.

Both cases are rather extreme and, in particular they are implausibly non-differentiable. The perfectly competitive model assumes that the tiniest wage cut results in the complete inability to recruit

\footnotetext{
${ }^{3}$ The Appendix also shows how if the interest rate is large, the labour market is not really competitive even if $\mathrm{C}_{\mathrm{N}}=0$.

${ }^{4}$ A simple modification of the formula would allow for this.
} 
any workers at all and the monopsony model assumes that there is nothing that an employer can do apart from raising the wage to recruit more workers than $\mathrm{N}^{\mathrm{s}}(\mathrm{w})$. The more reasonable case assumes differentiability and we stick to this case in what follows.

Let us now consider the optimal choice of the wage and employment. If we assume the firm has a revenue function $\mathrm{F}(\mathrm{N})$, steady-state profits can be written as:

$$
\pi=F(N)-[w+C(w, N)] N
$$

The firm has a choice of the wage it can pay if it wants to maintain employment at N. It will obviously choose w to minimize direct and indirect labour costs so let us define the function ? $(\mathrm{N})$ as:

$$
\omega(N)=\min _{w} w+C(w, N)
$$

which, assuming that the labour cost function is differentiable, has the first-order condition:

$$
-1-C_{w}(w, N)=0
$$

Profits can then be written as:

$$
\pi=F(N)-\omega(N) N
$$

(6) should make apparent the relationship between the model presented here and the more familiar textbook models of perfect competition and monopsony. It is that the labour supply curve w(N) needs to be replaced by the labour supply curve ? $(\mathrm{N})$. As ? (N) is the relevant labour supply curve let us call it the effective labour supply curve. We can represent the decision problem for the employer as in Figure 2 with $w(N)$ replaced by ? $(\mathrm{N})$, the effective supply of labour to the firm. Unsurprisingly, it is going to be of some interest whether ? $(\mathrm{N})$ is increasing in $\mathrm{N}$ which would give us the equivalent of an upward-sloping labour supply curve.

By application of the envelope theorem to (4) we have that: 


$$
\omega^{\prime}(N)=C_{N}(w(N), N)
$$

where $w(N)$ is the wage chosen if employment is $N$. This shows that the effective labour supply curve facing the firm is upward-sloping if the labour cost function is increasing in employment. If the labour cost function is independent of employment then the effective labour supply curve facing the firm will be infinitely elastic and will be like the labour supply curve in a perfectly competitive market. However it is important to note that one can have this result even if the wage elasticity of labour supply to the firm is not infinite so that the labour market appears at first sight monopsonistic.

Now let us consider the employment decision of the firm. One can write the first-order condition for employment as:

$$
F^{\prime}(N)=\omega(N)+\omega^{\prime}(N) N
$$

The right-hand side of (8) is simply the marginal cost of the effective labour supply curve facing the firm.

To bring out the importance of the slope of the $\omega(\mathrm{N})$ function let us consider the classic issue that divides perfect competition and monopsony, the impact of the minimum wage.

\section{The Impact of a Minimum Wage}

In this section, we consider the classic example where the predictions of perfect competition and monopsony differ: the imposition of a binding minimum wage equal to $\mathrm{w}_{\min }$. In the standard monopsony case this makes the labour supply curve facing the firm horizontal wherever it would otherwise pay a wage below the minimum. In the model here, the relevant question is how the minimum wage affects the slope of the effective labour supply curve.

If we are interested in the effect of the minimum wage on employment we need to consider its impact on the effective marginal cost of labour. As in the standard monopsony case, there are two effects - see (8). The minimum wage raises ? (N) but reduces ? $\mathrm{N}$ ). The total effect on the marginal cost of labour can be written as: 


$$
\frac{\partial M C L}{\partial_{w_{\min }}}=1+C_{w}\left(w_{\min }, N\right)+C_{w N}\left(w_{\min }, N\right)
$$

There are some situations in which we can sign this. Suppose the minimum wage just binds: then, from (5) we must have $\left(1+\mathrm{C}_{\mathrm{w}}\right)=0$ and the impact of the minimum wage on employment depends on the sign of $\mathrm{C}_{\mathrm{wN}}$. In the eompetitive $=$ ase where $\mathrm{C}_{\mathrm{N}}=\mathrm{C}_{\mathrm{wN}}=0$ the marginal effect on employment is zero (as the wage is chosen to minimize the total labour cost, the minimum wage has a zero first-order effect on ? (N)): but any minimum wage above the level chosen by the employer will reduce employment as we will then have the case $C_{w N}=0$ and $\left(1+C_{w}\right)>0$ (see Martin, 1997, for a specific application of this result).

However in the 'non-competitive' case, (9) shows that, if $\mathrm{C}_{\mathrm{wN}}<0$, then a just-binding minimum wage reduces the marginal cost of labour and raises employment: if $\mathrm{C}_{\mathrm{wN}}>0$ then the opposite happens. Which of these cases is more plausible? To answer this question, consider the relationship between ? (N) and the wage paid in the absence of the minimum wage. By differentiating (5) we will have that:

$$
\operatorname{sgn}\left(\frac{\partial w}{\partial N}\right)=-\operatorname{sgn}\left(C_{w N}(w, N)\right)
$$

(10) shows that the sign of $\mathrm{C}_{\mathrm{wN}}$ determines the sign ( $\left.\mathrm{M} / \mathrm{MN}\right)$. As ? (N) is increasing in employment this is equivalent to the issue of whether the wage paid by the employer rises or falls as we move up the effective labour supply curve, ? (N). If $\mathrm{C}_{\mathrm{wN}}<0$ then the wage rises and if $\mathrm{C}_{\mathrm{wN}}>0$ the wage falls. One can then readily understand the different impacts of the minimum wage in the two cases. If $_{\mathrm{wN}}<0$ then a minimum wage alters ? $(\mathrm{N})$ in the manner shown by the direction of the arrow in Figure 3a. The marginal cost of labour is lowered by a just-binding minimum wage in this case. In contrast, if $\mathrm{C}_{\mathrm{wN}}>0$ then a binding minimum wage alters ? $(\mathrm{N})$ in the manner shown by the direction of the arrow in Figure $3 b$.

The case $\mathrm{C}_{\mathrm{wN}}<0$ seems more plausible for a number of reasons. It is consistent with the robust empirical finding of a positive employer-size wage effect. Secondly, it will be guaranteed if $C(w, N)$ is multiplicatively separable and $\mathrm{C}_{\mathrm{N}} \$ 0$ and $\mathrm{C}_{\mathrm{w}}<0$ so that a higher wage reduces expenditure on training and recruitment (e.g. by reducing separation rates).

Given this discussion, it should be apparent that the form of the labour cost function $\mathrm{C}(\mathrm{w}, \mathrm{N})$ is 
of some importance. The labour market is mnonopsonistic $=$ if $\mathrm{C}_{\mathrm{N}}>0$ so that the non-wage costs are increasing in employment and æompetitive $\underset{\mp}{\rightarrow} \mathrm{C}_{N}=0$. Although there is a reasonable argument for using the labour cost function $\mathrm{C}(\mathrm{w}, \mathrm{N})$ in all the analysis that follows, and that analysis suggests we should focus on the effective labour supply function? (N) rather than the labour supply function w(N), this is hard to do as we rarely have the requisite data on non-wage labour costs like training and recruitment costs. However, the next section uses data on recruitment and training costs from a British survey to attempt to estimate the labour cost function.

\section{The Data}

The data used in this paper comes from the Labour Turnover Survey conducted by the UK Institute for Personnel Development every year from 1997 to 1999 . These surveys were the latest in a series of postal surveys of personnel professionals in the private and public sectors: in the 3 years there are a total of 2016 responding firms. The survey asks questions about the number of staff that have left and been recruited over the previous year for 10 broad occupational groups, on recruitment difficulties, redundancy and, importantly from our point of view, the costs of labour turnover. This makes the data set rather unusual and justifies its use here (since Oi's pioneering 1962 study which uses data from 1951 there have been hardly any papers written on the size of turnover costs). But, unfortunately, information on the level of pay is missing and there is only very rudimentary information on establishment characteristics. We discuss how to deal with the lack of wage information below.

Table 1a compares the sectoral distribution of the respondents with the distribution of employment from the UK Labour Force Survey (LFS). The most striking deviation from the population distribution is the larger fraction of employment in the IPD sample from the public sector. This is because the public sector is over-represented in IPD membership because of the greater professionalisation of the personnel function there. Table $1 \mathrm{~b}$ compares the occupational distribution of employment in the IPD compared to the LFS: there are fewer discrepancies here. However, one other important way in which the establishments in our sample differ from the population is their size. All of the IPD respondents refer to groups with more than 100 workers, while $50 \%$ of individuals are in workplaces that are smaller than this.

Table 2 presents some information on the size of turnover costs. The data on turnover costs in 
this data set comes from a question that asks:

Af possible please indicate by ticking the relevant box the estimated cost of turnover

(e.g. recruitment and training costs) per individual employee for each of the following occupational groups within your organisation@

The replies were banded and the answers by occupation are given in the top rows of Table 2 and the final line gives the average using the mid-point of each band as the average within bands and 15000 for the top band (different methods of computing the average turnover cost do not make much difference). As can be seen, turnover costs are highest at about $£ 4800$ for managerial and professional staff and lowest for unskilled workers and operatives where $£ 1000$ is a more reasonable estimate. We need to multiply this by the labour turnover rate to get the per-period cost. The average labour turnover rates per year are reported in the next row, and, converted to a weekly rate, are multiplied by the average turnover cost in the following row. One can see that the gap in the turnover costs between higherskilled and lower-skilled workers is now much smaller as turnover rates are higher for less-skilled workers. To get some idea of the importance of turnover costs, we need to relate this to the average weekly wage. The IPD data does not have information on wages so we have simply taken average earnings for each of the occupations from the Labour Force Survey (LFS). The next row shows these average weekly earnings and the final row then computes the turnover cost as a percentage of earnings. Turnover costs are highest in percentage terms for sales workers at over $10 \%$ of wage costs but the next highest group is clerical workers at $4.8 \%$. There no longer seems to be any particular relationship between turnover costs and skill levels so turnover costs would seem to be as important at the bottom end of the skills distribution as at the top. 35 years ago, Oi estimated turnover costs in one company (International Harvester) in one year (1951) at $7.3 \%$ of labour costs for all employees but $4.1 \%$ for common labourers. We have few more recent estimates: Campbell (1993) has an implicit average estimate of about $8 \%$ (though he does not explicitly report this statistic). The overall level of turnover costs here are similar.

Attention in this section has focused on the level of turnover costs. But, as the previous section showed, it may not be the level of turnover costs but how they change with the wage and level of recruitment activity that is important for answering questions about how labour markets work. 


\section{Estimating the Labour Cost Function}

In this section we present some estimates of the labour cost function using the Labour Turnover Survey data. As will be shown, we cannot, with the data available estimate all of the function but we can test the hypothesis of whether the marginal cost of a recruit is increasing in the level of recruits.

Suppose that the cost of a given level of recruits can be written as the following iso-elastic function of the wage, recruitment and employment:

$$
\ln C(w, R, N) \equiv c-\alpha \ln (w)+\beta_{0} \ln (R)-\beta_{1} \ln (N)
$$

Both the level of recruitment and employment are included to allow for the possibility (amongst others) that it is the ratio of recruitment to employment that determines the costs of recruitment. We would like to be able to estimate this function but, unfortunately, the IPD data has no data on wages. However, we can still obtain some insight into the marginal costs of recruitment. Assume that the separation rate can be written as $\ln (\mathrm{s})=\mathrm{s}-? \ln (\mathrm{w})$. Then, as $\mathrm{sN}=\mathrm{R}$, the labour cost function can be written as the following function of $\mathrm{w}$ and $\mathrm{N}$ :

$$
\ln C(w, N) \equiv c+\beta_{0} s-\left(\alpha+\beta_{0} \gamma\right) \ln (w)+\left(\beta_{0}-\beta_{1}\right) \ln (N)
$$

so that it is $\beta \equiv \beta_{0}-\beta_{1}$ that determines whether there diseconomies of scale in recruitment. The wage will be chosen to satisfy (5) which can be written as:

$$
\ln (w)=\frac{\left(c+\beta_{0} s\right)+\ln \left(\alpha+\beta_{0} \gamma\right)+\beta \ln (N)}{1+\alpha+\beta_{0} \gamma}
$$

which, substituting into (0.12) leads to:

$$
\ln C \equiv \frac{1}{1+\alpha+\gamma \beta_{0}}\left[c+\beta_{0} s+\beta \ln (N)\right]-\frac{\alpha+\gamma \beta_{0}}{1+\alpha+\gamma \beta_{0}} \ln \left(\alpha+\gamma \beta_{0}\right)
$$

(14) expresses the labour cost function in terms of $\mathrm{N}$ alone. Note, that the coefficient on $\mathrm{N}$ is not the $B$ 
in which we are interested but $\beta /\left(1+a+\gamma \beta \beta_{0}\right)$ so the coefficient is biased towards zero. But one can still look to see whether there is evidence that $\beta>0$.

In estimating (14) there is an endogeneity problem associated with the fact that unobserved differences in turnover costs that are in the error in our equation are likely to be negatively correlated with the level of recruits. It is not clear that much can be done about this except to notice that this will tend to bias our coefficients towards zero so that a finding that $\beta>0$ remains convincing evidence against the hypothesis that $\beta=0$.

Table 3 presents some estimates of the labour cost function of (14) using the IPD data. In the first row, all the observations are pooled together and job, sector and year controls are included and an interval regression is estimated. The coefficient on the log of employment is 0.050 and is significantly different from zero. This is evidence that $\beta>0$ and the labour cost function is increasing in employment. The next row estimates the model by OLS using mid-points of the turnover cost bands as measures of the turnover costs: this makes little difference to the estimated coefficient. The third row estimates a more demanding model where individual firm dummies are included. The coefficient drops (as we might expect from the likely increase in the importance of measurement error) but still remains significantly different from zero so that recruitment costs are significantly higher within a firm, in occupations where there is a high level of employment.

The rest of the table investigates the robustness of the estimates by estimating the same specification for the private and public sector. As can be seen, the results are robust. One might also wonder about whether there are significant differences by occupation. Table 4 examines this by estimating separate models for each occupation for all sectors and for the public and private sectors separately. All but two of the estimated employment elasticities are positive and none of the negative ones are significantly different from zero. There is some evidence that diseconomies of scale in recruitment are weaker for unskilled manual workers.

These results are supportive of the view that the supply of recruits to the firm is not perfectly elastic at a given level of costs and, hence that the labour market is monopsonistic. Given the likely downward biases in the estimates, the true extent of diseconomies in recruitment is likely to be greater than found here.

\footnotetext{
${ }^{5}$ The Appendix also shows how if the interest rate is large, the labour market is not really competitive even if $\mathrm{C}_{\mathrm{N}}=0$.

${ }^{5}$ A simple modification of the formula would allow for this.
} 


\section{Conclusions}

This paper has presented a simple model of the labour market that nests both the textbook competitive and monopsony models in a more general framework. It has shown how the key issue for whether labour markets are best thought of as 'competitive' or 'monopsonistic' is whether there are diseconomies of scale in recruitment. Using British data we have presented some evidence of such diseconomies which implies that the total cost of labour to a firm is increasing in the level of employment and, hence, it is best to think of the labour market as monopsonistic. 
Table 1a

The Representativeness of the IPD Labour Turnover Survey Dataset: Industry

\begin{tabular}{|l|c|c|}
\hline Percentage of Employment & IPD & LFS \\
\hline $\begin{array}{l}\text { Agriculture, Hunting, Forestry and } \\
\text { Fishing }\end{array}$ & 0.10 & 1.76 \\
\hline Mining and Extraction & 0.30 & 0.39 \\
\hline Manufacturing & 10.04 & 18.31 \\
\hline Electricity, Gas and Water & 1.18 & 0.69 \\
\hline Construction & 0.97 & 6.99 \\
\hline Wholesale and Retail Trade & 11.10 & 15.66 \\
\hline Hotels, Restaurants and Leisure & 0.88 & 4.50 \\
\hline $\begin{array}{l}\text { Transport, Storage and } \\
\text { Communication }\end{array}$ & 4.38 & 6.55 \\
\hline Health and Social Work & 14.52 & 11.41 \\
\hline Education & 3.43 & 7.88 \\
\hline $\begin{array}{l}\text { Finance, Insurance and Real Estate, } \\
\text { and Business Services }\end{array}$ & 19.53 & 14.52 \\
\hline Government & 31.36 & 6.03 \\
\hline Other Community Services & 2.21 & 5.30 \\
\hline
\end{tabular}

Notes:

1. The IPD data is employment-weighted for comparability with the LFS. The LFS data comes from the LFS from March 1997 to February 2000.

Table $1 b$

The Representativeness of the IPD Labour Turnover Survey Dataset: Occupation

\begin{tabular}{|l|c|c|}
\hline Percentage of Employment & IPD & LFS \\
\hline Managers and Administrators & 12.5 & 16.0 \\
\hline Professional & 14.2 & 10.5 \\
\hline $\begin{array}{l}\text { Associate Professional, Technical } \\
\text { and Scientific }\end{array}$ & 11.9 & 10.0 \\
\hline Clerical and Secretarial & 16.7 & 15.3 \\
\hline Sales & 6.8 & 8.2 \\
\hline Personal and Protective Services & 6.7 & 10.9 \\
\hline Craft and Skilled Manual & 8.2 & 11.9 \\
\hline Plant and Machine Operatives & 17.1 & 9.3 \\
\hline Other & 6.0 & 7.8 \\
\hline
\end{tabular}

Notes:

1. The IPD data is employment-weighted. The LFS data comes from the LFS from March 1997 to February 2000. 
Table 2

The Size of Turnover Costs

\begin{tabular}{|c|c|c|c|c|c|c|c|c|c|c|}
\hline & & manager-ial & $\begin{array}{l}\text { profess- } \\
\text { ional }\end{array}$ & technical & clerical & sales & personal & $\begin{array}{c}\text { Craft and } \\
\text { Skilled }\end{array}$ & operatives & unskilled \\
\hline \multirow{7}{*}{$\begin{array}{c}\text { turnover } \\
\text { cost } \\
(£)\end{array}$} & $<, 750$ & 6.0 & 3.7 & 6.0 & 23.9 & 15.3 & 31.7 & 35.5 & 63.1 & 44.8 \\
\hline &, $750-, 1500$ & 11.0 & 8.7 & 15.9 & 33.6 & 15.8 & 33.6 & 32.2 & 24.5 & 19.1 \\
\hline & $\begin{array}{l}1500- \\
, 3000\end{array}$ & 22.7 & 24.2 & 32.6 & 29.8 & 26.8 & 20.8 & 22.6 & 9.3 & 22.4 \\
\hline & $\begin{array}{l}, 3000- \\
, 5000\end{array}$ & 27.8 & 28.6 & 22.7 & 8.8 & 19.1 & 9.1 & 6.5 & 1.6 & 7.7 \\
\hline & $\begin{array}{l}, 5000- \\
, 7500\end{array}$ & 15.1 & 17.9 & 13.3 & 2.6 & 12.4 & 1.5 & 1.9 & 0.4 & 3.3 \\
\hline & $\begin{array}{l}, 7500- \\
, 10000\end{array}$ & 9.2 & 9.7 & 5.7 & 1.0 & 6.3 & 2.2 & 0.7 & 0.5 & 1.0 \\
\hline & $>, 10000$ & 8.2 & 7.0 & 3.7 & 0.3 & 4.3 & 1.1 & 0.5 & 0.5 & 1.7 \\
\hline \multicolumn{2}{|c|}{ average turnover cost $()}$, & 4749 & 4823 & 3736 & 1783 & 3574 & 1777 & 1528 & 1170 & 937 \\
\hline \multicolumn{2}{|c|}{ turnover rate ( $\%$ per year) } & 15.6 & 23.4 & 19.0 & 26.2 & 26.6 & 28.4 & 23.7 & 28.3 & 34.2 \\
\hline \multicolumn{2}{|c|}{$\begin{array}{l}\text { turnover rate } * \text { turnover } \\
\text { cost }(, \text { per week })\end{array}$} & 15.2 & 20.6 & 14.1 & 10.1 & 17.7 & 7.4 & 7.5 & 6.5 & 6.3 \\
\hline \multicolumn{2}{|c|}{ average weekly earnings } & 482 & 449 & 353 & 208 & 158 & 169 & 294 & \multicolumn{2}{|c|}{262} \\
\hline \multicolumn{2}{|c|}{$\begin{array}{c}\text { turnover cost as fraction } \\
\text { of total cost }\end{array}$} & 3.1 & 4.6 & 4.0 & 4.8 & 11.2 & 4.4 & 2.6 & 2.4 & 2.4 \\
\hline
\end{tabular}


Table 3

The Costs of Recruitment

\begin{tabular}{|c|c|c|c|c|c|c|c|}
\hline Sample & $\begin{array}{c}\text { Estimation } \\
\text { Method }\end{array}$ & $\begin{array}{l}\text { Coefficient } \\
\text { on } \\
\text { Ln(Employm } \\
\text { ent) }\end{array}$ & $\begin{array}{c}\text { Firm } \\
\text { Controls }\end{array}$ & $\begin{array}{c}\text { Sector } \\
\text { Controls }\end{array}$ & $\begin{array}{c}\text { Job } \\
\text { Controls }\end{array}$ & $\begin{array}{l}\text { Number } \\
\text { of Obs }\end{array}$ & $\mathrm{R}^{2}$ \\
\hline All & $\begin{array}{c}\text { Interval } \\
\text { Regression }\end{array}$ & $\begin{array}{c}0.060 \\
(0.008)\end{array}$ & No & Yes & Yes & 4761 & \\
\hline All & OLS & $\begin{array}{c}0.059 \\
(0.009)\end{array}$ & No & Yes & Yes & 4761 & 0.40 \\
\hline All & OLS & $\begin{array}{c}0.023 \\
(0.008)\end{array}$ & Yes & No & Yes & 4819 & 0.61 \\
\hline $\begin{array}{l}\text { Private } \\
\text { Sector }\end{array}$ & $\begin{array}{c}\text { Interval } \\
\text { Regression }\end{array}$ & $\begin{array}{c}0.064 \\
(0.010)\end{array}$ & No & Yes & Yes & 3508 & \\
\hline $\begin{array}{l}\text { Private } \\
\text { sector }\end{array}$ & OLS & $\begin{array}{c}0.063 \\
(0.010)\end{array}$ & No & Yes & Yes & 3508 & 0.41 \\
\hline $\begin{array}{l}\text { Private } \\
\text { Sector }\end{array}$ & OLS & $\begin{array}{c}0.033 \\
(0.012)\end{array}$ & Yes & No & Yes & 3508 & 0.65 \\
\hline $\begin{array}{l}\text { Public } \\
\text { Sector }\end{array}$ & $\begin{array}{c}\text { Interval } \\
\text { Regression }\end{array}$ & $\begin{array}{c}0.064 \\
(0.015)\end{array}$ & No & Yes & Yes & 1253 & \\
\hline $\begin{array}{l}\text { Public } \\
\text { Sector }\end{array}$ & OLS & $\begin{array}{c}0.064 \\
(0.015)\end{array}$ & No & Yes & Yes & 1253 & 0.37 \\
\hline $\begin{array}{l}\text { Public } \\
\text { Sector }\end{array}$ & OLS & $\begin{array}{c}0.035 \\
(0.017)\end{array}$ & Yes & No & Yes & 1253 & 0.74 \\
\hline
\end{tabular}

Notes:

1. All standard errors are hetero-scedastic consistent. 
Table 4

The Costs of Recruitment: Differences by Occupation

\begin{tabular}{|c|c|c|c|c|c|c|}
\hline & \multicolumn{2}{|c|}{ All } & \multicolumn{2}{|c|}{ Private sector } & \multicolumn{2}{|c|}{ Public Sector } \\
\hline sample & $\begin{array}{c}\text { Coefficient } \\
\text { (S.e.) }\end{array}$ & $\begin{array}{c}\text { Number of } \\
\text { obs }\end{array}$ & $\begin{array}{c}\text { Coefficient } \\
\text { (S.e.) }\end{array}$ & $\begin{array}{c}\text { Number of } \\
\text { obs }\end{array}$ & $\begin{array}{c}\text { Coefficient } \\
\text { (S.e.) }\end{array}$ & $\begin{array}{c}\text { Number } \\
\text { of obs }\end{array}$ \\
\hline managerial & $\begin{array}{c}0.067 \\
(0.024)\end{array}$ & 907 & $\begin{array}{c}0.080 \\
(0.027)\end{array}$ & 646 & $\begin{array}{c}0.031 \\
(0.045)\end{array}$ & 261 \\
\hline professional & $\begin{array}{c}0.109 \\
(0.020)\end{array}$ & 618 & $\begin{array}{c}0.118 \\
(0.024)\end{array}$ & 413 & $\begin{array}{c}0.091 \\
(0.037)\end{array}$ & 205 \\
\hline technical & $\begin{array}{c}0.094 \\
(0.023)\end{array}$ & 561 & $\begin{array}{c}0.119 \\
(0.028)\end{array}$ & 393 & $\begin{array}{c}0.044 \\
(0.039)\end{array}$ & 168 \\
\hline clerical & $\begin{array}{c}0.108 \\
(0.020)\end{array}$ & 859 & $\begin{array}{c}0.114 \\
(0.027)\end{array}$ & 615 & $\begin{array}{c}0.090 \\
(0.040)\end{array}$ & 244 \\
\hline Sales & $\begin{array}{c}0.061 \\
(0.032)\end{array}$ & 443 & $\begin{array}{c}0.048 \\
(0.032)\end{array}$ & 409 & $\begin{array}{c}0.291 \\
(0.161)\end{array}$ & 34 \\
\hline personal & $\begin{array}{c}0.105 \\
(0.053)\end{array}$ & 155 & $\begin{array}{c}0.129 \\
(0.076)\end{array}$ & 74 & $\begin{array}{c}0.068 \\
(0.077)\end{array}$ & 81 \\
\hline Craft/skilled & $\begin{array}{c}0.064 \\
(0.029)\end{array}$ & 450 & $\begin{array}{c}0.040 \\
(0.036)\end{array}$ & 349 & $\begin{array}{c}0.133 \\
(0.043)\end{array}$ & 101 \\
\hline operatives & $\begin{array}{c}0.019 \\
(0.036)\end{array}$ & 358 & $\begin{array}{c}0.016 \\
(0.038)\end{array}$ & 331 & $\begin{array}{l}-0.023 \\
(0.101)\end{array}$ & 27 \\
\hline unskilled & $\begin{array}{c}0.020 \\
(0.021)\end{array}$ & 410 & $\begin{array}{l}-0.007 \\
(0.026)\end{array}$ & 278 & $\begin{array}{c}0.078 \\
(0.035)\end{array}$ & 132 \\
\hline
\end{tabular}

Notes:

1. The dependent variable is for the log of the recruitment cost per worker.

2. Sector dummies, job dummies (where appropriate) and year dummies are included.

Regressions are weighted using the level of employment. 
Figure 1a

The Labour Cost Function: Perfect Competition

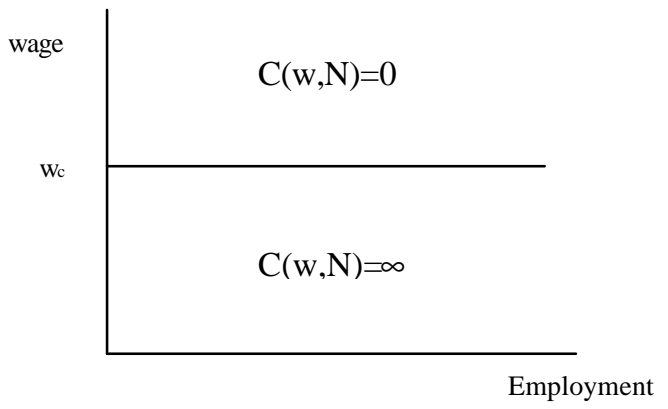

Figure 1b

The Labour Cost Function: Monopsony

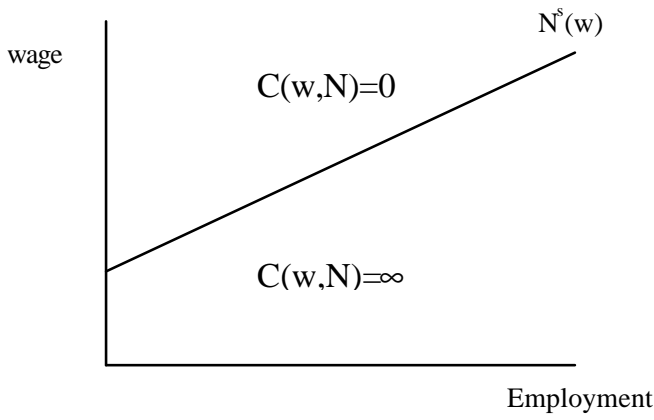

Figure 2

The Effective Labour Supply Curve of the Firm

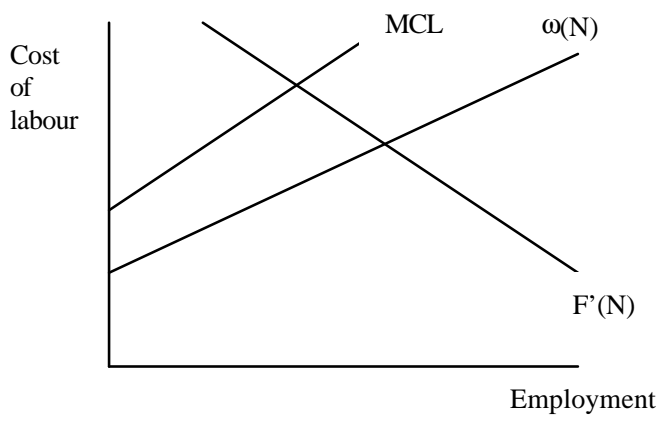


Figure 3a

The Effect of a Minimum Wage on the Effective Labour Supply Curve: $\mathrm{C}_{\mathrm{wN}}<0$

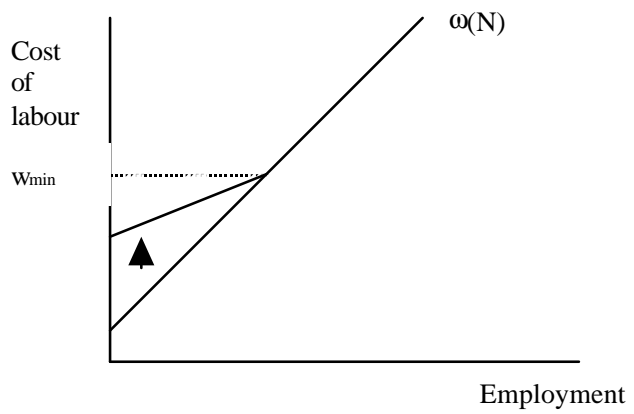

Figure $3 b$

The Effect of a Minimum Wage on the Effective Labour Supply Curve: $\mathrm{C}_{\mathrm{wN}}>0$

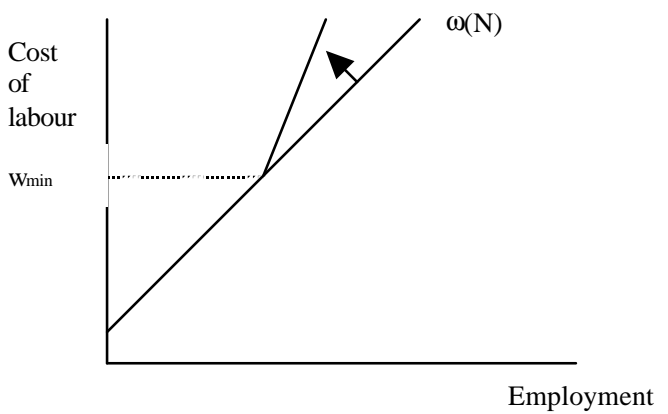




\section{Appendix}

\section{A Dynamic Version of the Model}

Suppose that the per-recruit cost of hiring and training $\mathrm{R}$ recruits if the wage paid is $\mathrm{w}$ can be written as $\mathrm{H}(\mathrm{R}, \mathrm{w})$. Assume that the separation rate is a function $\mathrm{s}(\mathrm{w})$ of the wage.

Define a value function $\Pi(\mathrm{N})$ to be the discounted value of profits if the employer has employment equal to $\mathrm{N}$. Then we will have:

$$
r \Pi(N(t))=\max _{\{R(t) w(t)\}} F(N(t))-w(t) N(t)-H(R(t), w(t)) R(t)+\Pi^{\prime}(N(t)) N^{\prime}(t)
$$

subject to the constraint:

$$
N^{\prime}(t)=R(t)-s(w(t)) N(t)
$$

Substituting (16) into (15) gives us:

$$
r \Pi(N(t))=\max _{\{R(t) w(t)\}} F(N(t))-w(t) N(t)-H(R(t), w(t)) R(t)+\Pi^{\prime}(N(t))(R(t)-s(w(t)) N(t))
$$

The first-order condition for $\mathrm{R}(\mathrm{t})$ in this problem can be written as:

$$
-H-R H_{R}+\Pi^{\prime}=0
$$

and the first-order condition for $w(t)$ as:

$$
-N-H_{w} R-\Pi^{\prime} . s^{\prime} N=0
$$

Additionally, there is the envelope condition that can be written as:

$$
r \Pi^{\prime}=F^{\prime}-w-s \Pi^{\prime}+\Pi^{\prime \prime}(R-s N)
$$


In a steady-state, we will have $\mathrm{R}=\mathrm{sN}$ so that $(20)$ can be written as:

$$
(r+s) \Pi^{\prime}=F^{\prime}-w
$$

which simply says that the marginal value of an extra worker is the gap between the marginal product and the wage divided by $(\mathrm{r}+\mathrm{s})$.

Substituting (21) into (18) leads to:

$$
\frac{F^{\prime}-w}{r+s}=H+R H_{R}
$$

and, using (18) to eliminate $\Pi$ ' from (19) leads to:

$$
-N-H_{w} R-\left(H+R H_{R}\right) \cdot s^{\prime} N=0
$$

Now, define the labour cost function to be $\mathrm{C}(\mathrm{N}, \mathrm{w})=\mathrm{H}(\mathrm{s}(\mathrm{w}) \mathrm{N}, \mathrm{w}) \mathrm{s}(\mathrm{w})$. Using the fact that, in steadystate, $\mathrm{R}=\mathrm{sN}$, the first-order conditions (22) and (23) can be written as:

$$
F^{\prime}-w=\frac{r+s(w)}{s(w)}\left[C+N C_{N}\right]
$$

and:

$$
-1-C_{w}=0
$$

If $r=0$, then these reduce to the first-order conditions from the static problem in the paper from the maximization of (3) with respect to $\mathrm{N}$ and (5).

If $r>0$, things are not identical. But, they are more favourable to the monopsony case. To see this, consider the example where $\mathrm{C}_{\mathrm{N}}=0$ so that we can write $\mathrm{C}(\mathrm{N}, \mathrm{w})$ as $\mathrm{s}(\mathrm{w}) \mathrm{H}(\mathrm{w})$. The first-order condition for employment can then be written as $\mathrm{F}^{\prime}(\mathrm{N})=\mathrm{w}+[\mathrm{r}+\mathrm{s}(\mathrm{w})] \mathrm{H}(\mathrm{w})$, where the right-hand side is the effective cost of labour. But, the wage is chosen to minimize $[w+s(w) H(w)]$. So, when a justbinding minimum wage is imposed, the effective cost of labour must fall and employment must rise. 


\section{References}

Boal, W. (1995), 'Testing for Employer Monopsony in Turn-of-the-Century Coal Mining', Rand Journal of Economics, 26, pp. 519-536.

Burdett, K. and Mortensen, D. (1998), 'Equilibrium Wage Differentials and Employer Size', International Economic Review, 39, pp. 257-273.

Campbell, C. (1993), Do Firms Pay Efficiency Wages? Evidence with Data at the Firm Level', Journal of Labour Economics, 11, pp. 442-470.

Card, D. and Krueger, A. (1995), Myth and Measurement: The Economics of the Minimum Wage, Princeton University Press: Princeton.

Diamond, P. A. (1982), ‘Aggregate Demand Management in Search Equilibrium', Journal of Political Economy; 90(5), pp. 881-894.

Martin, C. (1997), 'Labour Turnover: Evidence from UK Establishments', unpublished, Brunel University.

Mortensen, D. (1998), 'Equilibrium Unemployment With Wage-Posting: Burdett-Mortensen Meet Pissarides', unpublished, Northwestern University, http://www.faculty.econ.nwu.edu/faculty/mortensen/postmatch.pdf

Mortensen, D. and Pissarides, C. A. (1999), 'New Developments in Models of Search in the Labor Market', in O. Ashenfelter and D. Card (eds), Handbook of Labor Economics, vol. 3b, North-Holland: Amsterdam.

Nelson, P. (1973), 'The Elasticity of Labor Supply to the Individual Firm', Econometrica, 41, pp. 853-866.

Oi, W. (1962), ALabour as a Quasi-Fixed Factor@Journal of Political Economy, 70, pp. 538-555.

Pissarides, C. A. (1990), Equilibrium Unemployment Theory, Blackwell: Oxford.

Reynolds, L (1946), 'The Supply of Labour to the Firm', Quarterly Journal of Economics, 60, pp. 390-411.

Salop, S. C. (1979), 'A Model of the Natural Rate of Unemployment', American Economic

Review, 69, pp. 117-125.

Staiger, D., Spetz, J. and Phibbs, C. (1999), 'Is There Monopsony in the Labor Market? Evidence From a Natural Experiment', NBER Working Paper No. 7258. 
Sullivan, D. (1989), 'Monopsony Power in the Market for Nurses', Journal of Law and Economics, 32, pp. S135-178. 


\section{CENTRE FOR ECONOMIC PERFORMANCE Recent Discussion Papers}

\begin{tabular}{|c|c|c|}
\hline 498 & A. Charlwood & $\begin{array}{l}\text { Why Do Non-Union Employees Want to Unionise? } \\
\text { Evidence from Britain }\end{array}$ \\
\hline 497 & $\begin{array}{l}\text { M. Keil } \\
\text { D. Robertson } \\
\text { J. Symons }\end{array}$ & Minimum Wages and Employment \\
\hline 496 & $\begin{array}{l}\text { A. Di Liberto } \\
\text { J. Symons }\end{array}$ & Education and Italian Regional Development \\
\hline 495 & $\begin{array}{l}\text { S. Redding } \\
\text { A. J. Venables }\end{array}$ & Economic Geography and International Inequality \\
\hline 494 & A. Bryson & $\begin{array}{l}\text { Union Effects on Managerial and Employee Perceptions of } \\
\text { Employee Relations in Britain }\end{array}$ \\
\hline 493 & D. Metcalf & British Unions: Dissolution or Resurgence Revisited \\
\hline 492 & $\begin{array}{l}\text { R. Gomez } \\
\text { S. M. Lipset } \\
\text { N. Meltz }\end{array}$ & $\begin{array}{l}\text { Frustrated Demand for Unionisation: the Case of the } \\
\text { United States and Canada Revisited }\end{array}$ \\
\hline 491 & $\begin{array}{l}\text { S. Burgess } \\
\text { J. Lane } \\
\text { D. Stevens }\end{array}$ & Jobs, Workers and Changes in Earnings Dispersion \\
\hline 490 & $\begin{array}{l}\text { S. Burgess } \\
\text { S. Profit }\end{array}$ & $\begin{array}{l}\text { Externalities in the Matching of Workers and Firms in } \\
\text { Britain }\end{array}$ \\
\hline 489 & $\begin{array}{l}\text { S. Nickell } \\
\text { G. Quintini }\end{array}$ & Nominal Wage Rigidity and the Rate of Inflation \\
\hline 488 & $\begin{array}{l}\text { S. Nickell } \\
\text { J. Van Reenen }\end{array}$ & $\begin{array}{l}\text { Technological Innovation and Performance in the United } \\
\text { Kingdom }\end{array}$ \\
\hline 487 & M. M. Tudela & Explaining Currency Crises: A Duration Model Approach \\
\hline 486 & D. Sturm & Product Standards, Trade Disputes and Protectionism \\
\hline 485 & $\begin{array}{l}\text { G. Duranton } \\
\text { V. Monastiriotis }\end{array}$ & $\begin{array}{l}\text { Mind the Gaps: The Evolution of Regional Inequalities in } \\
\text { the UK 1982-1997 }\end{array}$ \\
\hline 484 & $\begin{array}{l}\text { H. G. Overman } \\
\text { Y. Ioannides }\end{array}$ & Zipfs Law for Cities: An Empirical Examination \\
\hline
\end{tabular}


483 H. G. Overman

Y. Ioannides

482 Y. Ioannides

H. G. Overman

481 H. G. Overman

$480 \quad$ S. Gomulka

479

S. Nickell

T. Jones

G. Quintini

478 C. Dougherty

$477 \quad$ P. Willman

476 D. Marsden

S. French

K. Kubo

475 S. Gomulka

474 S. Burgess

H. Turon

473 D. Robertson

J. Symons

472 B. Bell

S. Nickell

G. Quintini

471 M. Dabrowski

S. Gomulka

J. Rostowski

$470 \quad$ B. Petrongolo

C. A. Pissarides
Cross Sectional Evolution of the US City Size Distribution

Spatial Evolution of the US Urban System

Neighbourhood Effects in Small Neighbourhoods

Pension Problems and Reforms in the Czech Republic, Hungary, Poland and Romania

A Picture of the Job Insecurity Facing British Men

Numeracy, Literacy and Earnings: Evidence from the

National Longitudinal Survey of Youth

The Viability of Trade Union Organisation: A Bargaining Unit Analysis

Why Does Performance Pay De-Motivate? Financial Incentives versus Performance Appraisal

Macroeconomic Policies and Achievements in Transition Economies, 1989-1999

Unemployment Dynamics, Duration and Equilibrium:

Evidence from Britain

Factor Residuals in SUR Regressions: Estimating Panels Allowing for Cross Sectional Correlation

Wage Equations, Wage Curves and All That

Whence Reform? A Critique of the Stiglitz Perspective

Looking Into the Black Box: A Survey of the Matching Function 